Article

\title{
Does the Revised Hukou System Facilitate or Restrain the Short-Term Labor Inflows into Chinese Cities?
}

\author{
Hao Cui ${ }^{1}$ and Joonmo Cho ${ }^{2, *}$ \\ 1 School of Economics and Management, Yanbian University, Yanji 133002, China; cui.hero@gmail.com \\ 2 Department of Economics, Sungkyunkwan University, Seoul 110745, Korea \\ * Correspondence: trustcho@skku.edu
}

Received: 3 December 2019; Accepted: 4 February 2020; Published: 11 February 2020

\begin{abstract}
According to previous studies, the Chinese revised Hukou system has not been proven to be effective in the short-term movement of the rural labor force or in controlling urban populations. In this study, we address and analyze the self-selection problem from the perspective of inflows of short-term migration from the rural labor force and the endogeneity problem in the adoption of the revised Hukou system, based on the data from China Family Panel Studies (CFPS). The study shows that the revised Hukou system adopted by Chinese local governments was significantly efficient and harmed the short-term migration decisions of the rural labor force.
\end{abstract}

Keywords: the revised Hukou system; rural labor force; short-term mobility; policy endogeneity; self-selection

\section{Introduction}

Since the Chinese government launched economic reforms in 1978, the demand for urban labor has increased with the development in the east coast cities, for example in the special economic zone (SEZ), and with the rapid economic growth in the private sector. As the rural labor force entered cities, there was a rapid increase in the urban population. Since the early 2000s, the labor migration rate has been continuously decreasing due to a migrant labor shortage (mingonghuang, 民工荒). Accordingly, the Chinese administration quickly adopted the revised Hukou system to solve the urban labor force supply shortage problem by redistributing the rural labor force.

The trends and features of rural-urban migration and the temporal pattern of urbanization in China before the 1990s were mainly determined by the economic development strategy, which was a major intervention on the part of the Chinese government [1]. The strict control and standardization of China's Hukou system has led to a new spatial pattern and trend of internal migration. This system has enabled China to create a huge migrant labor force, promoting the rapid development of China's manufacturing industry and increasing urbanization [2]. Since 1990, Western Chinese scholars such as Christiansen, Chan, Cheng and Seiden, and Mallee have studied the important issues related to the Hukou system and population mobility, as well as the system's social and economic impacts. They believe that the Hukou system is one of the main social control tools used by the central government. The function of the Hukou system extends far beyond simply controlling population mobility [3-7].

Since 1978, China's reforms in rural and urban areas have produced a large surplus of rural labor supply, while at the same time urban areas have also seen a large demand for effective labor, causing a new trend of labor mobility in urban and rural areas [8]. The rural labor force flowing into large urban areas is gradually expanding, and most of these workers are engaged in difficult, dirty, dangerous (3D) jobs, such as in the construction industry. This labor force has facilitated unprecedented urbanization [9]. Moreover, the migration of rural surplus labor is closely related to the economic development of a certain location, which also contributes to the urban population and economic 
growth [10]. However, under the restriction of the Hukou system, migrant workers cannot integrate into the urban environment and cannot enjoy public welfare and social security benefits [11]. If these rural laborers want to attain equal income and welfare to their urban counterparts, they have to overcome the restrictions of the Hukou system and become permanent urban migrants; however, the odds of this are slim [12]. With the gradual development of the rural labor market, the opportunity for rural labor to shape the labor market has also expanded. There has also been a reduction in migration space and time in the rural labor force. Trained and skilled rural laborers more often choose to relocate permanently and tend to choose high-income, non-agricultural employment, transitioning themselves into a new urban professional labor force $[13,14]$. Some domestic scholars have also proposed that the Hukou reform implemented during this period had no significant impact on the short-term rural labor flow, and that the efficiency of the Hukou reform was low [15].

Between 2001 and 2012, the significant increase in permanent immigration led to development and urbanization in certain regions. However, these outcomes were not considered to be a result of the revised Hukou system adoption. Indeed, other factors, such as the income gap between urban and rural regions and the characteristics of migrant labor, were considered to be the major growth impetus. The larger the city, the slower the execution of the residence permit system (Juzhuzheng) [16].

After national reform, Hukou reform can be divided into four or five stages [17,18]. Among them, the period before the State Council issued "Policies on the Reform of Household Registration System", in 2014, was the stage when some local governments represented by the Guangdong province promoted the Hukou reform. We choose this stage of 2000-2013 to assess the impact of the Hukou reform adopted by some local governments on short-term rural labor mobility.

The movement patterns of the labor force can be divided into long-term and short-term. The Hukou system and the self-selecting mechanism are interlocked, as local governments consider resident characteristics for system adoption, while the labor force considers the Hukou system as their long-term migration method. Migration that has self-selecting characteristics needs to be considered simultaneously with and separately from the Hukou reform. However, for short-term migration, which we will look into later in this study, higher income is expected without receiving urban public welfare services, such as medical and education benefits.

The adoption of the revised Hukou system depends on a city's characteristic variables. A local government's decisions on the Hukou reform are based on a thorough consideration of a city's characteristics. A city's characteristics, which influence not only the migration selection but also the adoption of the revised Hukou system, lead to endogenous problems. In other words, mechanisms for the short-term migration of rural labor forces versus adoption of city policy for the long-term implementation of the Hukou system are different matters. Simply adjusting self-selection problems that exist for short-term migration will not solve the endogenous problems that result from a city's adoption of the revised Hukou system. Therefore, in this study we address the self-selection problem related to short-term mobility and the endogeneity problem related to the revised Hukou system separately, and analyze the net effect of labor mobility.

Using the recent China Family Panel Studies (CFPS) data, a group of ongoing studies by the institute of Social Science Survey (ISSS) of Peking University (2010-2014), and individual labor force panel data, we include in this study the variables that directly influence labor force migration to examine the effectiveness of the revised Hukou system by resolving the endogeneity and self-selection problems. Namely, we address the hypothesis that the Hukou reform promoted by the local government does not affect the short-term flow of rural labor. Through the analysis of this research hypothesis, the net effect of the Hukou reform on labor mobility is assessed.

In Section 2, the revised Hukou system and historical factors are compared. In Section 3, the previous studies and the effect of the revised Hukou system on labor force migration are discussed. In Section 4, suggestions are provided to address self-selection and endogeneity problems, as well as a description of the modeling. Part V consists of a basic statistical analysis of data used in this study, graphic analysis 
of the labor migration routes, and empirical analysis of the flow of labor force. Lastly, the results of this study and discussions are provided.

\section{Previous Literature}

In terms of labor supply, previous literature on labor force flow was mostly microscopic, based on factors such as gender, age, education level, the experience of the labor force, and characteristics such as family size, parental education level and living environment, and, for labor demand, macroscopic studies were analyzing the effects of market factors on labor flow [19-21]. Analysis on population movements in five European countries from 1980 to 1990 and the China population census in 1990 both showed that labor forces preferred to move to cities with great market benefits because of the economic gap, and primarily migrated to regions where abundant consumer goods and life conveniences were available [22,23].

As a result of a regional analysis on the permanent shift from rural Hukou to urban Hukou residency in 2002, the economic conditions of the permanent migrants largely improved compared to that of farmers who remained in rural areas. Major factors affecting such permanent migration were level of parents' education, followed by ethnic characteristics of the Han (Hanzu, Han is the major ethnic group (comprising approximately 91.5\%) among 56 ethnic groups in China according to the Consensus in 2010), and then the parents' Communist Party membership, etc., all with positive correlations. The economic status of permanent migrants is related to their age at conversion to urban Hukou; the younger the age, the higher the income. Meanwhile, many migrants who obtained urban Hukou with non-employment often were unable to adapt to the urban lifestyle [12,24-26].

The empirical analysis of the effectiveness of regional Hukou reform between 2003 and 2006 showed that the reform had minimal impact on the short-term movement of the labor force and was limited in encouraging or promoting migration of the rural labor force. Meanwhile, social networks and higher income levels in rural areas were found to have significant effects on the migration of the rural labor force [15]. Such social networks and higher income in rural areas were also found to have significant effects on rural labor force movements.

Analysis on the rural areas Liaoning and Jilin in 2009 showed that Hukou reform was not significant in short-term rural labor force migration. The welfare from Land Contract System and Hukou, low expected income, and high opportunity cost is correlated with policies [27].

Previous studies on rural labor force flow by Hukou reform concluded that the reform had a weak impact. Notably, for the short-term labor force, the confidence for higher income or job opportunities more actively influenced movements [28].

\section{Background of the Revised Hukou System}

In the early days of China's foundation, the Hukou system did not restrict population movement. However, as urban populations surged, with a large inflow of the rural population, problems in food, clothing, and shelter emerged along with congested social disorders and safety issues. The population flow started to be severely restricted by the unconstitutional (constitutional reform in 1975 abolished "Freedom of Migration", which has not been recovered until today) People's Republic of China Account Registration Ordinance [29], established in 1958. The ordinance classified urban and rural households as "Urban Hukou" and "Rural Hukou", thereby classifying China's urban citizens and rural farmers into two different social structures and, in turn, causing discrimination in policy benefits and restrictions.

Since the Chinese economic reform, the Hukou system has changed to manage and control population flow by dividing the population into Resident Population (urban Hukou permanent resident), the Temporary Resident Population (non-urban Hukou for short-term residents), and the Temporary Resident for Working Population (non-urban Hukou for long-term residents). The residency for each classification was issued based on the Residents' Identity Cards System [30] introduced in 1984, and the Interim Provisions on Urban Population Management [31], introduced in 1985. 
From 2007, a pilot of Urban and Rural Hukou Unitary was started in 12 provinces and cities including Guangdong, revoking previous household classifications and instead implementing a uniform Juzhuzheng System [32]. Guangdong also expanded the Juzhuzheng target to all the migrant labor force from 1 January 2010 [33]. Since then, subsequent Hukou regulations and policies were established in surrounding cities and regions. In November 2013, the central government of China announced a plan to promote population management and Hukou reform [34].

As shown in Figure 1, since the implementation of the Hukou system, which restricted freedom of migration, the income gap between urban and rural areas had always remained 3-fold. However, in terms of inflation accounting for monetary value, the actual income gap increased from 2700 Yuan per capita from 1985 to 1989 , to 82,000 Yuan from 2010 to 2014 by approximately 30-fold, resulting in a difference of 80,000 Yuan. [35]
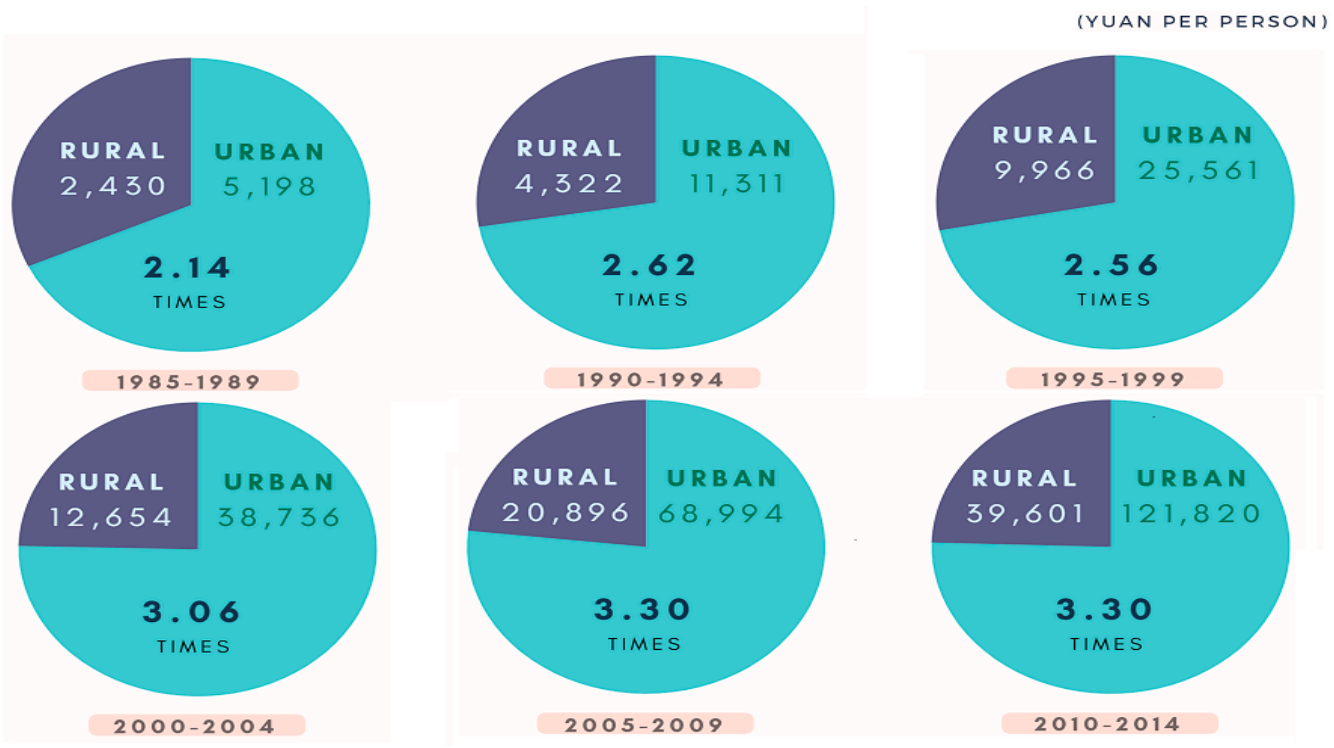

Figure 1. Urban-Rural Income Gap (1985-2014) by China Statistics book.

Changes in rural areas happened not only in the income but also in the overall industrial structures. Figure 2 shows that the proportion of the labor force in the agricultural sector (Agriculture, Forestry, Livestock, Fishery) decreased from $92.8 \%$ in 1979 to $57.8 \%$ in 2008. During the same period new employment was created in wholesale, trade and catering sectors (from $0.0 \%$ to $6.2 \%$ ) and the other sectors (from $0.0 \%$ to $12.1 \%$ ). Employment in the construction sector (from $0.5 \%$ to $7.7 \%$ ) and transport, warehouse and post sector (from $0.2 \%$ to $3.2 \%$ ) increased by about 16 times, and in the industrial (mining and manufacturing) sector (from 2.7\% to 13.0\%) by about four times. As excess labor force from the agricultural sector found employment in other sectors within the same region or moved to urban regions for higher pay, migration between urban and rural regions became popular and diverse job selection options became available for the labor force previously engaged in the agricultural sector [35].

Government and officials utilized the Hukou system that discriminated against rural areas as an essential means for strategic industrialization. The adoption of a biased system, which mainly focused on benefits for urban residents, who are the core workforce for industrial development, led to neglect of the needs of rural residents. It became the basis for economic development and a reason for support from the urban residents which led to the further expansion of the Hukou system. The urban residents had stronger advocacy than rural residents, which was another reason why the redistribution of wealth centered on urban regions. Urban citizens were able to enjoy privileges from the distribution of welfare benefits, such as housing and healthcare service, according to the fixed quantity distribution system, as well as privileges such as a stable employment guarantee. 


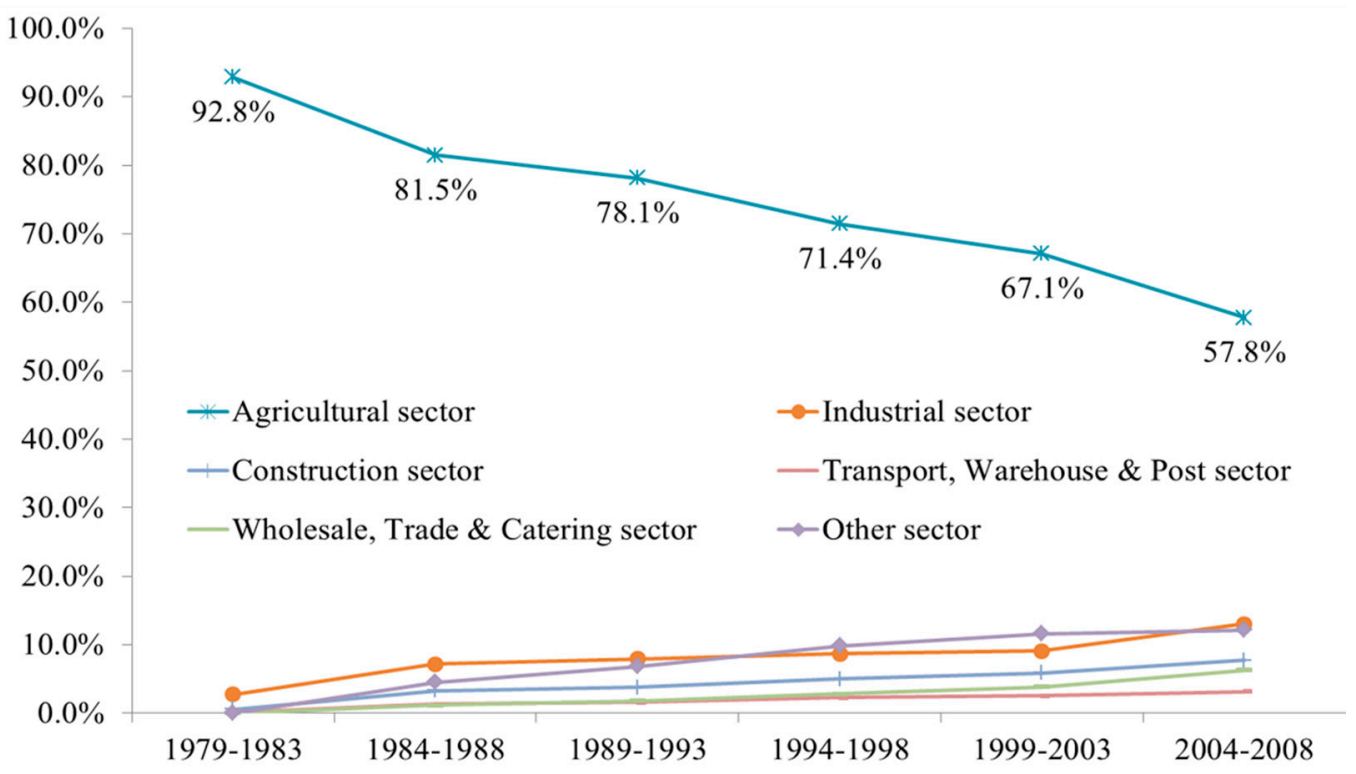

Figure 2. Employment rates by Industry in Rural Areas (1979-2008) by China Statistics book.

\section{Empirical Analysis Modeling}

\subsection{Labor Force Migration and Self-Selection}

The two factors that determine labor force migration are the external pull force and the internal push force. The most significant pull factor in both domestic and overseas labor migration is the income gap, followed by the living environment and educational opportunities. Meanwhile, the excess labor force of potential migration is the most significant push factor. Some studies say that if there were no surplus of labor force other than the rural labor force, there would be no moving labor force searching for work [36,37]. In previous studies, demographic attributes (i.e., age, gender, and health conditions), the number of people who were able to participate in economic activities in the family, and the conditions surrounding the residence (natural resources, farmland size, taxes, travel time and distance to cities) were demonstrated as push factors in migration [38]. However, it is a self-selecting behavior for the labor force to migrate in search of jobs and higher income. Men with young and robust physique, who are often favored in the urban labor market in China, are more likely to decide, or prefer to, migrate. Such selection behavior is influenced not only by observable factors but also by potential unobservable attributes that are difficult to recognize. Adding the independent dummy variable, that indicates whether or not the revised Hukou system is in place, may bias the results, as the sample contains both the labor force that are affected and those not affected by the revised Hukou system. This is because the migration decision made by self-selection can be affected by many other reasons besides the revised Hukou system. To address the self-selection problems, we use the Heckman two-stage Model (Heckit model) in this study.

\subsection{Policy Endogeneity of the Revised Hukou System}

This study aims to assess the effectiveness of the revised Hukou system on rural labor force short-term migration. However, the revised Hukou system was not uniformly adopted by the central government during the period of analysis; instead it was executed region by region, resulting in it losing its exogeneity and being influenced by local and government characteristic variables.

Each local government makes a decision on the Hukou system based on their local characteristics, governance structures, and the demands of the establishment. Local traits and government characteristics influence the decision on labor forces migration and Hukou system adoption, which causes endogeneity problems. In this case, the decision on Hukou reform adoption affects the labor forces' migration decision as an endogenous variable. People tend to choose to migrate to cities 
that have adopted the revised Hukou system. The revised Hukou system encourages freedom of movement, so migrants are more likely to select such cities which promote an inflow of the labor force. Therefore, the omitted variables of each endogeneity problem are comprised of reform decisions and local government's characteristics. In reality, the revised Hukou system, implemented by local governments, is leading to political decisions for local economic development and the protection of urban citizens' rights.

In this study, we use the average wage level of workers in urban formal sectors [39] and the level of urban public service supply, which are considered as the necessary factors for Hukou reform, as Instrument Variables (IVs) (the Entropy Method used in Tiebout model was used for the local public service supply level. The city's medical facilities, welfare facilities, education facilities, economic amenities were used as index). First, the Hukou system itself has the characteristics of discriminating the rural migrants to protect urban Hukou labor in the urban formal sector. Moreover, such protection still exists in the revised Hukou system. To be employed in the public state-owned official organizations, or "Shiye Danwei", being urban Hukou is a requirement, and the probability of employment increases with higher education levels and specific schools. Such workers are hired as permanent employees with secured employment or "Tiefanwan," and their wages would be regularly raised depending on their experiences and competencies. On the other hand, rural Hukou holders are excluded from Shiye Danwei's hiring objectives. In other words, rural migrants have to search for opportunities in the informal sector because they are excluded from being hired in the urban formal sector. Therefore, we use the average wage level of workers in the urban formal sector as an IV, as it is directly correlated to the adoption of the revised Hukou system while having no association with the dependent variable-migration selection of the rural labor force. The robustness test is also conducted to determine the quantitative adequacy of the IV.

As the government's expenditure in the public service sector increases, urbanization would progress, and the living environment of the citizens would improve. The size of public welfare facilities such as hospitals and public transportation is often considered in many studies as an indicator of urbanization. [40-45] Financial expenditures on educational facilities, from kindergarten through to universities, and amenities such as shopping centers are commonly considered as public service provisions for urban citizens. Only urban Hukou holders are eligible to obtain urban healthcare insurance and freely use urban healthcare facilities, while the rural Hukou holders are discriminated against in rural medical insurance and are required to have prior approval when using urban healthcare facilities with limited insurance coverage. Welfare benefits such as free urban public transportation rides are also only given to urban Hukou residents. Public educational facilities were also only accessible by urban Hukou residents, and rural Hukou residents could not receive a public education from kindergartens or schools in the city until 2015. From 2015, in a few regions, the government has attempted to allow admission to the children of rural Hukou residents who moved to urban areas, but they are being discriminated against due to issues that arise in the Juzhuzheng. For these reasons, the level of public service provision in the urban area has no direct effect on the rural labor force's decision to migrate, but it has a decisive influence on the discriminative Hukou system and is an appropriate IV for solving the endogeneity problem. In addition, the data on the average wage level of the urban formal sector worker and public service supply level are used with migration data that happened in the same year, because the national statistical data are released in October of the following fiscal year, which does not reflect real correlation.

The previous studies used natural disasters and the income level of the previous year as IVs for analysis on the labor force migration and the income changes after migration. These IVs can be used as dependent variables in models to analyze changes in income level. In our model, we use the migration of the rural labor force as a dependent variable and each local Hukou reform as an explanatory variable. Our research goal is to analyze the effectiveness of the revised Hukou system in rural labor force migration. Therefore, our model includes variables that decide Hukou reform rather than IVs such as natural disasters or previous year income, as in previous studies. These variables play an important 
role in Hukou reform but do not affect the migration of the rural labor force. The suitability test of IVs used in this study is based on the Wald Test proposed by Wooldridge (2010). Overestimation of IVs and the model's robustness will be tested using the Weak-instrument-robust tests for IV estimation by IV-Heckit model.

\subsection{Analysis Model}

In this study, however, we focus only on short-term shifts in rural labor forces, whose migration purpose is mostly income generation. Therefore, self-selection and the problem of endogeneity in the process of adopting the revised Hukou system should be separately analyzed. We also try to empirically analyze the theoretical estimations about the adoption of the system and migration through each robustness testing in a separate analysis. In the empirical analysis, we modified the methods of previous studies to meet the purpose of this study and compared three different methods for results analysis [46].

The first method is the Probit model, in which $L M_{i g}$, the dependent variable in bivariate form represents the migration of labor entity; $1=$ select migration and $0=$ not select migration. $i$ represents all sample entities, while $g$ represents the migration destination of the sample entity, or residence of the sample entity for entities that did not migrate. $H_{g}$ is a variable indicating whether or not the revised $H u k o u$ system was adopted to analyze the direct effect of the adoption of the revised Hukou system on rural labor force migration. $X_{i g}$ is a control variable that includes independent variables representing the attributes of labor entities. $V_{g}$, as one of the control variables, includes regional minimum wage, as we assume that an income that's higher than current income level is preferred when a labor force decides to migrate. $\beta_{i}$ is the coefficient value of each independent variable, and the error term $\epsilon$ is assumed to follow the bivariate normal distribution. Here, the adoption of the revised Hukou system variable $H_{g}$ is the most important independent variable, and $\beta_{i}$ indicates the effectiveness of the Hukou reform. We used a dummy variable to indicate whether or not the adoption of the revised Hukou system took place.

$$
L M_{i g}=\beta_{0}+\beta_{1} H_{g}+\beta_{2} X_{i g}+\beta_{3} V_{g}+\epsilon
$$

The second method attempts to address the self-selection problem with the Heckit model based on the Probit model and consists of Equations (2) and (3). $\widehat{H u k o u}_{i g}$, used in Equations (2) and (3), refers to the Inverse Mill's Ratio (IMR) value; "Hukou" is either a rural Hukou or an urban Hukou. $O_{i g}$ is the omitted variable that indicates the characteristics of the residing area of the labor force before migration, and this variable does not correlate with $L M_{i g}$ but the Hukou characteristics $\left(H u k o u_{i g}\right)$. All independent variables of Equation (2) are the subset of Equation (3), and $\mu$ is the error term. By addressing the self-selection problem, the effectiveness of the revised Hukou system adoption on the migration of rural labor force is expected to be more accurately analyzed.

$$
\begin{aligned}
& L M_{i g}=\beta_{0}+\beta_{1} H_{g}+\beta_{2} X_{i g}+\beta_{3} V_{g}+\beta_{4} \widehat{H u k o u}_{i g}+\epsilon \\
& \text { Hukou }_{i g}=\gamma_{0}+\gamma_{1} O_{i g}+\gamma_{2} H_{g}+\gamma_{3} X_{i g}+\gamma_{4} V_{g}+\mu
\end{aligned}
$$

In the third method, to solve the endogeneity problem, we modify models from previous studies by adding the average wage level of workers in the urban formal sector and the public service supply level in urban areas as the IV set $\left(I V_{g}\right)$ to the Heckit model. $\eta$ is the error term. To solve the endogeneity problem in the adoption of the revised Hukou system, using an IV estimation method that affects the adoption of the revised Hukou system and is irrelevant to migration selection by the rural labor force is important. The IVs used in the previous studies were excluded, as they did not fit in the purpose of this study. Instead, as a result of verification through other IVs, two factors with the highest 
relevance to the execution of the revised Hukou system adoption were added to the IV to properly fix the endogeneity problem.

$$
\begin{aligned}
& L M_{i g}=\beta_{0}+\beta_{1} \widehat{H_{g}}+\beta_{2} X_{i g}+\beta_{3} V_{g}+\beta_{4} \widehat{H u k o u}_{i g}+\epsilon \\
& \text { Hukou }_{i g}=\gamma_{0}+\gamma_{1} O_{i g}+\gamma_{2} I V_{g}+\gamma_{3} X_{i g}+\gamma_{4} V_{g}+\mu \\
& H_{g}=\alpha_{0}+\alpha_{1} I V_{g}+\alpha_{2} X_{i g}+\alpha_{3} V_{g}+\alpha_{4} \widehat{H u k o u}_{i g}+\eta
\end{aligned}
$$

By using the three methods mentioned above, the effect of the revised Hukou system on inflows of rural labor was analyzed.

\subsection{Data Analysis}

The data used in this study are the CFPS from 2010-2014. The reason why we chose 2010-2014 data is based on the setting of the research scope (2000-2014) and the data that can properly reflect the population migration at this stage. The study targets consist of 14,798 households and 33,600 adults in 2010, 13,315 households and 35,719 adults in 2012, and 13,946 households and 37,147 adults in 2014. Tables 1 and 2 show the variables and descriptions used in the model. For this study, the number of labor forces who chose to migrate, in the dependent variable, is 4464 in 2010, 4556 in 2012, and 4949 in

\begin{tabular}{|c|c|}
\hline Variables & Descriptions \\
\hline Labor force migration $\left(L M_{i j}\right)$ & $\begin{array}{l}\text { Indicates movement of labor force entities. } \\
\text { moved }=1 ; \text { not moved }=0\end{array}$ \\
\hline $\begin{array}{l}\text { The revised } H u k o u \text { System } \\
\text { adoption }\left(H_{j}\right)\end{array}$ & $\begin{array}{l}\text { This is a binary variable that indicates whether the revised Hukou system has been adopted } \\
\text { or not. } \\
\text { Adopted }=1 \text {; Not-adopted }=0\end{array}$ \\
\hline Inflow & $\begin{array}{l}\text { When labor force moves into a region }=\text { Inflow } \\
\text { Note that, in some areas, the movements within the same area are excluded from inflow. } \\
\text { Inflow }=1\end{array}$ \\
\hline Hukou $\left(\mathrm{Hukou}_{i}\right)$ & $\begin{array}{l}\text { Classified as rural Hukou and urban Hukou. } \\
\text { Among urban citizens, there are residents with rural Hukou or urban Hukou. Set the Hukou } \\
\text { characteristics as binary variables. } \\
\text { Rural Hukou }=1 \text {; Urban Hukou }=0\end{array}$ \\
\hline Age $\left(\right.$ age $\left._{i}\right)$ & We set the age of the economically active labor force from 16 to 65 years. \\
\hline Education level $\left(e d u_{i}\right)$ & $\begin{array}{l}\text { The education level is classified from illiteracy to a Ph.D. The higher the observation, the } \\
\text { higher the level of education. In the case of illiteracy, which is the lowest level, } 1 \text { is given, } \\
\text { and in the case of Ph.D., the highest level of } 8 \text { is given. }\end{array}$ \\
\hline Married $\left(\right.$ married $\left._{i}\right)$ & $\begin{array}{l}\text { We assume marital status affects decision to migrate. } \\
\text { Married }=1 \text {; Single, Divorced, Widowed }=0\end{array}$ \\
\hline Family size (familysize ${ }_{i}$ ) & $\begin{array}{l}\text { Family size indicates the number of family members living together. In the previous study, } \\
\text { the larger the family size, the more active the shift in the labor force. This is because } \\
\text { surplus labor is generated. }\end{array}$ \\
\hline Life Satisfaction $\left(L S_{i}\right)$ & $\begin{array}{l}\text { Explains self-subjective evaluation of life satisfaction. As we use a survey conducted every } \\
\text { two years, life satisfaction is compared to the level from the last survey. } \\
5 \text { points scale: } 1 \text {. Very dissatisfied; } 2 \text {. Unsatisfied; } 3 \text {. Normal; } 4 \text {. Satisfied; } 5 \text {. Very satisfied }\end{array}$ \\
\hline $\log \left(\right.$ Min-wage) $\left(\right.$ ln_minwage $\left._{j}\right)$ & This displays the log of the minimum wage level in each region. \\
\hline $\begin{array}{l}\text { Residence Classification } \\
\qquad\left(\text { urban }_{i}\right)\end{array}$ & $\begin{array}{l}\text { A binary variable that distinguishes between urban or rural areas with the characteristics } \\
\text { of the area in which one currently resides. } \\
\text { Rural }=1 ; \text { Urban }=0\end{array}$ \\
\hline $\log ($ Job wage $)\left(l_{-} \_\right.$jobwage $\left.j\right)$ & Indicates the logarithm of the average wage level of workers in each urban formal sector. \\
\hline $\begin{array}{l}\text { The level of public service } \\
\text { supply } \\
\left(\operatorname{cov}_{j}\right)\end{array}$ & $\begin{array}{l}\text { The level of supply of urban public services for urban Hukou residents. Using the entropy } \\
\text { method for the local public service provision used in the Tiebout model, four public service } \\
\text { provision levels were indexed, namely, urban medical facilities, welfare facilities, } \\
\text { educational facilities, and economic living facilities. }\end{array}$ \\
\hline
\end{tabular}
2014, respectively.

Table 1. Variables and Descriptions. 
Table 2. Descriptive Statistics for Key Variables.

\begin{tabular}{|c|c|c|c|c|c|c|}
\hline & \multicolumn{2}{|c|}{2010} & \multicolumn{2}{|c|}{2012} & \multicolumn{2}{|c|}{2014} \\
\hline & Migration & No-Migration & Migration & No-Migration & Migration & No-Migration \\
\hline & $(\mathrm{N}=4464)$ & $(\mathrm{N}=41,004)$ & $(\mathrm{N}=4556)$ & $(\mathrm{N}=40,912)$ & $(\mathrm{N}=4949)$ & $(\mathrm{N}=40,519)$ \\
\hline & \multicolumn{2}{|c|}{$\begin{array}{c}\text { Mean } \\
\text { (Standard Deviation) }\end{array}$} & \multicolumn{2}{|c|}{$\begin{array}{c}\text { Mean } \\
\text { (Standard Deviation) }\end{array}$} & \multicolumn{2}{|c|}{$\begin{array}{c}\text { Mean } \\
\text { (Standard Deviation) }\end{array}$} \\
\hline \multicolumn{7}{|l|}{ Personal Characteristics } \\
\hline \multirow[t]{2}{*}{ Age } & 29.17 & 40.84 & 30.10 & 41.14 & 30.35 & 41.66 \\
\hline & $(9.60)$ & $(13.87)$ & $(9.74)$ & $(13.99)$ & $(10.36)$ & $(13.92)$ \\
\hline \multirow[t]{2}{*}{ Age sq. } & 943.13 & 1860.58 & 1000.8 & $1,888.25$ & 1028.64 & 1928.85 \\
\hline & $(668.99)$ & $(1127.76)$ & $(688.16)$ & $(1143.04)$ & $(753.87)$ & $(1150.41)$ \\
\hline Education Level & 2.33 & 2.50 & 3.05 & 2.85 & 3.18 & 2.73 \\
\hline$(1-8,1=$ Low $; 8=$ High $)$ & $(1.20)$ & $(1.29)$ & $(1.18)$ & $(1.32)$ & (1.33) & (1.33) \\
\hline Marital Status & 1.60 & 1.92 & 1.62 & 1.92 & 1.69 & 1.93 \\
\hline (Single 1, Married 2) & $(0.61)$ & $(0.65)$ & $(0.63)$ & $(0.65)$ & $(0.68)$ & $(0.67)$ \\
\hline \multirow[t]{2}{*}{ Family Size } & 5.55 & 4.44 & 5.20 & 4.42 & 4.61 & 4.27 \\
\hline & $(2.07)$ & $(1.82)$ & $(2.11)$ & $(1.85)$ & $(2.04)$ & $(2.00)$ \\
\hline Life Satisfaction & 3.45 & 3.47 & 2.03 & 3.04 & 2.37 & 3.23 \\
\hline$(1-5,1=$ Low $; 5=$ High $)$ & $(1.04)$ & $(1.05)$ & $(1.78)$ & $(1.35)$ & $(1.96)$ & $(1.61)$ \\
\hline Personal Income & 8.17 & 8.69 & 9.55 & 9.52 & 8.68 & 8.79 \\
\hline$(\log )$ & $(1.57)$ & $(1.55)$ & $(1.15)$ & $(1.28)$ & $(2.43)$ & $(2.24)$ \\
\hline Wage & 9.70 & 9.77 & 10.66 & 10.17 & 10.33 & 10.34 \\
\hline$(\log )$ & $(0.99)$ & $(1.03)$ & $(0.84)$ & $(1.19)$ & $(1.15)$ & $(1.05)$ \\
\hline \multicolumn{7}{|l|}{ Regional Characteristics } \\
\hline Minimum Wage & 6.74 & 6.77 & 6.90 & 6.92 & 7.25 & 7.27 \\
\hline$(\log )$ & $(0.12)$ & $(0.12)$ & $(0.19)$ & $(0.18)$ & $(0.12)$ & $(0.13)$ \\
\hline Average Wage & 10.29 & 10.34 & 10.53 & 10.58 & 10.76 & 10.79 \\
\hline$(\log )$ & $(0.13)$ & $(0.22)$ & $(0.13)$ & $(0.21)$ & $(0.15)$ & $(0.20)$ \\
\hline Urbanization Ratio & 0.91 & 0.90 & 0.82 & 0.79 & 0.82 & 0.79 \\
\hline & $(0.09)$ & $(0.10)$ & $(0.09)$ & $(0.14)$ & $(0.12)$ & $(0.14)$ \\
\hline $\begin{array}{l}\text { Government } \\
\text { Expenditure }\end{array}$ & 2450.60 & 2483.9 & 3643.8 & 3680.7 & 4539.5 & 4814.2 \\
\hline (million Yuan) & (1091.98) & (956.09) & $(1667.36)$ & $(1402.71)$ & (1916.54) & (1840.45) \\
\hline \multirow{3}{*}{$\begin{array}{l}\text { Public Service Supply } \\
\text { Level }\end{array}$} & -0.14 & 0.02 & -0.11 & 0.02 & -0.01 & 0.05 \\
\hline & $(0.59)$ & $(0.74)$ & $(0.56)$ & $(0.68)$ & $(0.75)$ & $(0.80)$ \\
\hline & \multicolumn{2}{|c|}{ Freq. (Proportion ' $\%$ ') } & \multicolumn{2}{|c|}{ Freq. (Proportion '\%’) } & \multicolumn{2}{|c|}{ Freq. (Proportion '\%’) } \\
\hline \multicolumn{7}{|l|}{ Personal Characteristics } \\
\hline \multirow[t]{2}{*}{ Male } & 2820 & 20,409 & 2892 & 20,194 & 2551 & 20,535 \\
\hline & $(63.17)$ & $(49.77)$ & $(63.49)$ & $(49.64)$ & $(55.41)$ & $(50.46)$ \\
\hline \multirow[t]{2}{*}{ Female } & 1644 & 20,595 & 1663 & 20,485 & 2053 & 20,158 \\
\hline & (36.83) & $(50.23)$ & $(36.51)$ & $(50.36)$ & $(44.59)$ & $(49.54)$ \\
\hline \multicolumn{7}{|c|}{$\begin{array}{c}\text { Residence Characteristics (subject to } \\
\text { household) }\end{array}$} \\
\hline \multirow[t]{2}{*}{ Rural Areas } & 3501 & 24,071 & 2455 & 16,622 & 3238 & 21,990 \\
\hline & $(78.92)$ & $(59.10)$ & $(75.65)$ & $(56.58)$ & (70.87) & $(54.30)$ \\
\hline \multirow[t]{2}{*}{ Urban Areas } & 935 & 16,661 & 790 & 12,755 & 1331 & 18,506 \\
\hline & $(21.08)$ & $(40.90)$ & $(24.35)$ & $(43.42)$ & $(29.13)$ & $(45.70)$ \\
\hline \multicolumn{7}{|l|}{ The revised Hukou System } \\
\hline Not affected & 3189 & 26,868 & 3568 & 30,682 & 3397 & 31,916 \\
\hline & $(71.44)$ & $(65.53)$ & $(78.31)$ & $(75.00)$ & (73.78) & (78.10) \\
\hline Affected & 1275 & 14,136 & 988 & 10,230 & 1207 & 8948 \\
\hline & $(28.56)$ & $(34.47)$ & (21.69) & $(25.00)$ & $(26.22)$ & $(21.90)$ \\
\hline
\end{tabular}

The revised Hukou system, which is the main explanatory variable to be analyzed in this study, was adopted in the form of Juzhuzheng in seven provinces before 2010 and had been expanded to 19 provinces in 2014 (the ordinance was adopted in seven provinces (Sheng), including Shanghai, Shanxi, Liaoning, Jilin, Zhejiang, Anhui and Guangdong, and their cities before 2010, and was additionally extended to 12 provinces (Sheng) and their cities.). The details of the Juzhuzheng are different by region; industrial regions prioritize labor force attraction while population control is the major objective in metropolitan cities.

The average wage level of workers in the formal sector of urban regions where the labor forces migrated showed no correlation with the labor force migration selection according to the annual 
macroeconomic data from 2009 to 2014 published by the National Bureau of Statistics of the China, which indicates that the average wage level is determined to be an appropriate IV. As per the regional public service supply level, in 2010 the public service supply level was low in the regions selected as migration destinations compared to the non-migration destinations. Compared to the public service supply level in 2010, there was a slight increase in 2012 and 2014, but it remained low. This is contrary to the results from previous studies which suggested that a high level of public service supply attracts the labor force and leads to migration. This means that the public service supply level does not affect labor migration selection; therefore, it is a proper IV.

Regarding personal characteristics, the ages of both the groups that have selected and the groups that have not selected to migrate have increased. The signs of aging are shown not only in the urban but also in rural regions, and family size is continuously decreasing with a continuous low fertility rate. As the level of education gradually increases, the labor force with technical skills rather than with low skills tends to migrate more. The income level and the wage level difference is small between migrants and non-migrants, and the wage level of groups that migrated in 2012 is slightly higher than that of the non-migrant groups. Both income and wage levels had slightly increased since 2010 and had decreased in 2014 compared to 2012. In the same period, the life satisfaction rate decreased compared to that of 2010. The sharp increase in inflation and housing cost resulted in a decrease in life satisfaction rate among migrants compared to non-migrants, which led to decreased labor force migration and even a return phenomenon.

Despite the government's efforts towards urbanization the actual urbanization rate has been decreasing as the population of the rural Hukou residents living in urban areas increases. The initial purpose of the Hukou reform, implemented by local governments, is to select the migrated rural labor force and grant the urban Hukou the ability to expand the citizen population and revitalize the urban economy. As shown in the descriptive statistics, areas where the efforts of local governments towards Hukou reform are weak are preferentially selected by the rural labor force as migration destinations.

\section{Results of Empirical Analysis}

For regional economic development, an additional labor force is needed, and urbanization can also be achieved as the migrant labor force settles down in their new cities. Under such a plan, the existing Hukou system, which is considered negative, should be abolished, and a unified, equal Hukou reform should be adopted.

The result of the analysis using the Probit model in Table 3 demonstrates that the revised Hukou system in recent years has been unhelpful in facilitating the inflow of the labor force. A similar negative outcome is also demonstrated in the Heckit model, in which the self-selection problem was addressed.

The statistics show that the revised Hukou system remained at the same scale in 2010 and 2012, which implies that the negative outcome had been slightly expanded. In 2014, negative effects were anticipated to decrease with the expansion in coverage of the revised Hukou system. The regional Hukou reforms were benchmarked from each other, so, in the process of simply deploying the system to another region, the endogeneity problem came along with it and, in turn, the negative effect was underestimated. In contrast, the IV-Heckit model, which is used to address an endogeneity problem that can overestimate the revised Hukou system's effectiveness, has shown that the effectiveness of the revised Hukou system was quite weak in all three years. This leads to the conclusion that, over time, the system adoption by local governments lags behind change in labor force movement. In particular, most of the rural labor force has the possibility of choosing short-term movements, except for the agricultural season. Even if they are not engaged in agricultural activities, a return to their rural hometown during the holiday season, from the New Year to the Lunar New Year, results in a renewed job search after the holiday. Due to such characteristics, the revised Hukou system, which seeks to secure a long-term and permanent labor force and migrants, is far from appropriate to serve its purpose. In other words, adoption of the new system lacks effectiveness even for short-term labor force migration selections and, as the speed of implementation is slow, it lacks timeliness as well. 
As is known, older individuals tend to migrate less, but the data in 2010 and 2012 show opposite results. The reason for the age increase in migration selection to cities was found to be the good living conditions, with access to welfare facilities and educational opportunities for children. Regarding life satisfaction, however, life satisfaction was slightly higher for rural residents [47], which is similar to previous studies. The higher the minimum wage in the area of current residence, the lower the expectation to migrate to other cities. However, other data showed opposite results, concluding that the impact of the minimum wage level on labor force migration was not significant. One of the most important reasons that the labor force chooses to migrate is to seek a better living environment for family members, as mentioned earlier. However, in the IV-Heckit model that addressed the problem of endogeneity for 2014 data, the characteristics of the individual showed opposite results to 2010 and 2012 data, implying that the influence of individual characteristics on rural labor force migration to urban areas is no longer effective.

In the IV including the Heckit model, the effectiveness of the revised Hukou system in 2010 was anticipated to have a huge drop of $68.3 \%$, compared to that of the Probit and Heckit models. It was 44.5\% lower in 2012, and the revised Hukou system was found to be ineffective enough to cause overestimation in 2014 (the results drawn by the simple IV Probit model to solve the endogeneity problem demonstrated the effectiveness of adopting of the revised Hukou system as -0.632 in 2010, -0.928 in 2012, and -0.590 in 2014, indicating that adopting the revised Hukou system was ineffective, similar to the results drawn by the IV-Heckit model). The reason for the drop is considered to be the adoption of the ineffective revised Hukou system in 2010 and further expanding its implementation in 2014. It is fair to doubt that the average wage level of workers in urban formal sectors, used as the IV, is supposed to play a role as a decision factor in rural labor force migration in normal circumstances. However, the official public statistical information provided is often unfriendly and hard to understand for many rural labor forces. In addition to being difficult to access and understand, it is challenging for the rural labor force to decide on migration because of the discrimination they foresee, as it has been deeply rooted in the culture for a long time. Therefore, we believe that the average wage level does not influence migration.

The IV which indicates the level of public service provision in the city is composed of the benefits only available to permanent urban Hukou residents, and does not have any influence on the migration of rural labor force. In the estimates of individual characteristics, we found that individual characteristics are significant in data from the last three years and tends to be similar to those of the previous two Probit and Heckit analysis. However, regarding education level, as opposed to in the Probit and the Heckit model, the accuracy of the IV-Heckit model was verified, as it drew the same results as previous studies, that the superior labor force inflow is from the rural area. The role of the IVs was significant, as the results demonstrated by the IV-Heckit model were more influential than those demonstrated by the Heckit models. Adoption of the revised Hukou system is inversely correlated with rural labor inflow and, with the adoption of the system, labor inflow is estimated to decrease, concluding that the system's effectiveness is weak. There are endogeneity problems in the revised Hukou system and the self-selection problem from Hukou classifications. We analyzed both models: the one that addressed the issue and the other that did not. From the result, we suspect slight overestimation but believe the IV-Heckit model is appropriate in solving the overall effectiveness of the revised Hukou system. Verification of IV through Wooldridge's Wald test, shown in Table 3, demonstrates that the endogeneity problem has been sufficiently addressed and the IVs has passed the overidentification test. In addition, the robustness test has also been passed, while addressing the endogeneity problem in every third year of biennial empirical analysis. In sum, with the two IVs, we analyzed the effectiveness and timeliness of the revised Hukou system more precisely by addressing the problem of endogeneity. 
Table 3. Estimation Results of Three Models: Rural Labor Force Inflow.

\begin{tabular}{|c|c|c|c|c|c|c|c|c|c|}
\hline \multirow{2}{*}{$\begin{array}{l}\text { Inflow of Labor Force } \\
\quad(1=\text { inflow })\end{array}$} & \multicolumn{3}{|c|}{2010} & \multicolumn{3}{|c|}{2012} & \multicolumn{3}{|c|}{2014} \\
\hline & Probit & Heckit & IV-Heckit & Probit & Heckit & IV-Heckit & Probit & Heckit & IV-Heckit \\
\hline $\begin{array}{c}\text { Adopted of the revised } \\
\text { Hukou system }\end{array}$ & $-0.021^{* * *}$ & $-0.025^{* * *}$ & $-0.683^{* * *}$ & -0.005 & $-0.048^{* * *}$ & $-0.445^{* * *}$ & $-0.012 * * *$ & $-0.011^{* *}$ & \\
\hline$(0=$ Non-in.; $1=$ In. $)$ & $(0.002)$ & $(0.006)$ & $(0.165)$ & $(0.004)$ & $(0.005)$ & $(0.126)$ & $(0.004)$ & $(0.005)$ & $(0.835)$ \\
\hline Age & $0.003^{* * *}$ & $0.002 * *$ & $0.059^{* * *}$ & $0.009 * * *$ & $-0.005^{* * *}$ & $0.083^{* * *}$ & -0.001 & -0.002 & 0.000 \\
\hline$(16-65)$ & $(0.000)$ & $(0.001)$ & $(0.008)$ & $(0.001)$ & $(0.001)$ & $(0.007)$ & $(0.001)$ & $(0.001)$ & $(0.006)$ \\
\hline Age sq. & $\begin{array}{l}-0.000^{* * *} \\
(0.000)\end{array}$ & $\begin{array}{c}-0.000^{* * *} \\
(0.000)\end{array}$ & $\begin{array}{c}-0.001^{* * *} \\
(0.000)\end{array}$ & $\begin{array}{l}-0.000 * * * \\
(0.000)\end{array}$ & $\begin{array}{c}0.000 \\
(0.000)\end{array}$ & $\begin{array}{c}-0.002^{* * *} \\
(0.000)\end{array}$ & $\begin{array}{l}-0.000^{* * *} \\
(0.000)\end{array}$ & $\begin{array}{c}-0.000^{* * *} \\
(0.000)\end{array}$ & $\begin{array}{l}-0.000 * * * \\
(0.000)\end{array}$ \\
\hline $\begin{array}{c}\text { Education Level } \\
(1=\text { low; } 8=\text { high })\end{array}$ & $\begin{array}{c}-0.002 * * * \\
(0.001)\end{array}$ & $\begin{aligned}-0.092^{* * *} & (0.002)\end{aligned}$ & $\begin{array}{c}0.019 \\
(0.016)\end{array}$ & $\begin{array}{c}-0.008^{* * *} \\
(0.001)\end{array}$ & $\begin{array}{c}-0.109^{* * *} \\
(0.001)\end{array}$ & $\begin{array}{c}0.079 * * * \\
(0.019)\end{array}$ & $\begin{array}{c}0.007^{* * *} \\
(0.001)\end{array}$ & $\begin{array}{c}-0.101^{* * *} \\
(0.001)\end{array}$ & $\begin{array}{c}0.264^{* * *} \\
(0.063)\end{array}$ \\
\hline $\begin{array}{c}\text { Gender } \\
(0=\text { female } 1=\text { male })\end{array}$ & $\begin{array}{c}0.024^{* * *} \\
(0.002)\end{array}$ & $\begin{array}{l}-0.001 \\
(0.005)\end{array}$ & $\begin{array}{c}0.370 * * * \\
(0.026)\end{array}$ & $\begin{array}{c}0.053^{* * *} \\
(0.003)\end{array}$ & $\begin{array}{c}0.016^{* * *} \\
(0.004)\end{array}$ & $\begin{array}{c}0.395^{* * *} \\
(0.025)\end{array}$ & $\begin{array}{c}0.022 * * * \\
(0.003)\end{array}$ & $\begin{array}{c}0.015^{* * *} \\
(0.004)\end{array}$ & $\begin{array}{c}0.105^{* * *} \\
(0.026)\end{array}$ \\
\hline $\begin{array}{l}\text { Marital Status } \\
(1=\text { unmarried })\end{array}$ & $\begin{array}{c}-0.006^{* * *} \\
(0.002)\end{array}$ & $\begin{array}{c}0.004 \\
(0.004)\end{array}$ & $\begin{array}{c}-0.096^{* * *} \\
(0.030)\end{array}$ & $\begin{array}{c}-0.025^{* * *} \\
(0.003)\end{array}$ & $\begin{array}{c}-0.008^{* *} \\
(0.004)\end{array}$ & $\begin{array}{c}-0.186^{* * *} \\
(0.028)\end{array}$ & $\begin{array}{c}0.012 * * * \\
(0.003)\end{array}$ & $\begin{array}{l}-0.005 \\
(0.003)\end{array}$ & $\begin{array}{c}0.107^{* * *} \\
(0.021)\end{array}$ \\
\hline Family Size & $\begin{array}{c}0.007^{* * *} \\
(0.000)\end{array}$ & $\begin{array}{c}0.018^{* * *} \\
(0.002)\end{array}$ & $\begin{array}{c}0.099 * * * \\
(0.006)\end{array}$ & $\begin{array}{c}0.010^{* * *} \\
(0.001)\end{array}$ & $\begin{array}{c}0.011^{* * *} \\
(0.001)\end{array}$ & $\begin{array}{c}0.047^{* * *} \\
(0.007)\end{array}$ & $\begin{array}{c}0.004^{* * *} \\
(0.001)\end{array}$ & $\begin{array}{c}0.006^{* * *} \\
(0.001)\end{array}$ & $\begin{array}{c}-0.026^{* *} \\
(0.012)\end{array}$ \\
\hline $\begin{array}{l}\text { Life Satisfaction } \\
(1=\text { low } ; 5=\text { high })\end{array}$ & $\begin{array}{c}0.000 \\
(0.001)\end{array}$ & $\begin{array}{l}0.005^{* *} \\
(0.002)\end{array}$ & $\begin{array}{l}-0.004 \\
(0.012)\end{array}$ & $\begin{array}{c}-0.031 * * * \\
(0.001)\end{array}$ & $\begin{array}{c}-0.008^{* * *} \\
(0.002)\end{array}$ & $\begin{array}{c}-0.244^{* * *} \\
(0.008)\end{array}$ & $\begin{array}{c}-0.024^{* * *} \\
(0.001)\end{array}$ & $\begin{array}{c}-0.007^{* * *} \\
(0.001)\end{array}$ & $\begin{array}{c}-0.134^{* * *} \\
(0.009)\end{array}$ \\
\hline $\begin{array}{c}\text { Minimum Wage } \\
\text { (log) }\end{array}$ & $\begin{array}{c}-0.162^{* * *} \\
(0.010)\end{array}$ & $\begin{array}{c}-0.195^{* * *} \\
(0.024)\end{array}$ & $\begin{array}{c}-1.647^{* * *} \\
(0.336)\end{array}$ & $\begin{array}{c}-0.034^{* * *} \\
(0.009)\end{array}$ & $\begin{array}{l}-0.017 \\
(0.016)\end{array}$ & $\begin{array}{c}0.383^{* *} \\
(0.190)\end{array}$ & $\begin{array}{c}-0.135^{* * *} \\
(0.013)\end{array}$ & $\begin{array}{c}-0.0325^{* *} \\
(0.016)\end{array}$ & $\begin{array}{c}0.298 \\
(0.382)\end{array}$ \\
\hline $\begin{array}{c}\text { Residence Char. } \\
(0=\text { Rural; } 1=\text { Urban }) \\
\text { Inflow IMR }\end{array}$ & & $\begin{array}{c}0.272 * * * \\
(0.004)\end{array}$ & $\begin{array}{c}0.310 * * * \\
(0.051) \\
-0.181^{*} \\
(0.095)\end{array}$ & & $\begin{array}{c}0.263^{* * * *} \\
(0.004)\end{array}$ & $\begin{array}{c}0.049 \\
(0.061) \\
-0.614^{* * *} \\
(0.093)\end{array}$ & & $\begin{array}{c}0.267^{* * * *} \\
(0.003)\end{array}$ & $\begin{array}{c}-0.205 \\
(0.200) \\
-0.680^{* * *} \\
(0.238)\end{array}$ \\
\hline Constant & & $\begin{array}{c}-0.346^{* * *} \\
(0.073)\end{array}$ & $\begin{array}{c}8.762 * * * \\
(2.226)\end{array}$ & & $\begin{array}{c}-0.404^{* * *} \\
(0.047)\end{array}$ & $\begin{array}{c}-3.909 * * * \\
(1.277)\end{array}$ & & $\begin{array}{c}-0.424^{* * *} \\
(0.041)\end{array}$ & $\begin{array}{l}-1.132 \\
(2.177)\end{array}$ \\
\hline Obs. & 30,453 & 20,749 & 29,983 & 24,668 & 23,208 & 22,855 & 32,243 & 30,389 & 28,461 \\
\hline Wald Test & & 0.000 & 0.033 & & 0.000 & 0.000 & & 0.000 & 0.003 \\
\hline
\end{tabular}

Note: Standard deviation is presented in parenthesis; ${ }^{* * *} p<0.01$ and ${ }^{* *} p<0.05$ means the statistically significant estimated value.* Wald test: Wald test of exogeneity prob (IV-Heckit); Wald test of independent prob (Heckit).

\section{Conclusions and Discussion}

By using the data from the China Family Panel Studies (CFPS) in 2010, 2012 and 2014, we assessed in this study the net effect of the revised Hukou system, and addressed the problem of policy endogeneity in the revised Hukou system adopted by each local government and the self-selection problem in short-term migration of the rural labor force.

As a result of addressing the self-selection problem with the Heckit model, the revised Hukou system showed a suppressing effect on the migration of the rural labor force, as shown in all 3-year data. Of the average five-person household, the family with a householder in his late 20s, with secondary education and a robust physique, has a high city adaptation level, and can move to cities and reduce the gap in competitiveness with previous residents. At the same time, the Hukou reform was empirically confirmed to have a suppressing effect on migration to cities. This counters the purpose of the revised Hukou system, which was supposed to legalize rural labor force migration without constraints.

Furthermore, because of the possibility of overestimating the effectiveness of the local government's adoption of the revised Hukou system due to its endogenous problem, we added the average wage level of workers in the urban formal sector and urban public service supply level as IVs to the Heckit model. As a result, the revised Hukou system was estimated to have low effectiveness.

In this paper, three research methods are used to better explain the negative effects of the household registration reform promoted by local governments. However, this analysis method cannot be the most correct and best analysis tool, and we will continue to improve the upgrading analysis method of the future household registration reform efficiency analysis and similar policy evaluation research.

Along with the problem of aging and low fertility, the labor force needed for urban development requires more inflow than outflows and local governments are actively working on plans for reform. In the case of Chongqing, the plan to transform 10 million farmers into urban citizens for ten years from 2010 is in progress. On the other hand, metropolitan cities like Beijing announced a list of industries that were banned from hiring the migrated rural labor force, creating an extremely negative regulation for unified labor market development, which is essential in the development of the market economy.

We empirically confirmed that, contrary to the original purpose of adopting the nondiscriminatory Hukou system, it has brought a more severe restraint of migration because the revised Hukou system 
was introduced to the selected groups especially in cities where labor force mobility was frequent. In particular, the short-term rural labor force migration, working in difficult, dirty, dangerous (3D) jobs, has faced more severe restraints on migration. If the restraints of the revised Hukou system were to disappear, it would be easier for many short-term migrants to choose longer-term migration or permanent migrations and they would benefit from urbanization while having stable jobs in the cities. The revised Hukou system tends to be limited to stimulating labor mobility for the development of the specific cities where it's adopted, and does not facilitate the general population redistribution in nation-wide China.

Author Contributions: H.C. conceptualized this research and contributed extensively to data curation and formal analysis, J.C. provided many suggestions for improving and modifying this article. All authors have read and agreed to the published version of the manuscript.

Funding: This research was funded by Sungkyunkwan University and Yanbian University.

Conflicts of Interest: The authors declare no conflict of interest.

\section{References}

1. Chan, K. Rural-Urban Migration in China, 1950-1982: Estimates and Analysis. Urban Geogr. 1988, 9, 53-84. [CrossRef]

2. Chan, K. Migration and Development in China: Trends, Geography and Current issues. Migr. Dev. 2012, 1, 187-205. [CrossRef]

3. Christiansen, F. Social Division and Peasant Mobility in Mainland China: The Implications of Hu-k'ou System. Issues Stud. 1990, 26, 78-91.

4. Chan, K. Cities with Invisible Walls: Reinterpreting Urbanization in Post-1949 China; Oxford University Press: Oxford, UK, 1994.

5. Cheng, T.; Seiden, M. The Origins and Social Consequences of China's Hukou System. China Q. 1994, 139, 644-668. [CrossRef]

6. Mallee, H. China's Household Registration System under Reform. Dev. Chang. 1995, 26, 1-29. [CrossRef]

7. Mallee, H. Reform of the Hukou System. Chin. Sociol. Anthropol. 1996, 29, 3-14. [CrossRef]

8. Seeborg, M.C.; Jin, Z.; Zhu, Y. The New Rural-Urban Labor Mobility in China: Causes and Implications. Socio-Econ. J. 2000, 29, 39-56. [CrossRef]

9. Roberts, K.D. The determinants of job choice by rural labor migrants in Shanghai. China Econ. Rev. 2001, 12, 15-39. [CrossRef]

10. Zhang, K.H.; Song, S. Rural-Urban Migration and Urbanization in China: Evidence from Time-series and Cross-section Analyses. China Econ. Rev. 2003, 14, 386-400. [CrossRef]

11. Fan, C.C. The State, the Migrant Labor Regime, and Maiden Workers in China. Polit. Geogr. 2004, 23, 283-305. [CrossRef]

12. Deng, Q.; Gustafsson, B. China's Lesser Known Migrants. Econ. Res. J. 2007, 4, 137-148.

13. Wang, X.; Thomas, H.; Thomas, G. Labor Allocation in Transition: Evidence from Chinese Rural Households. China Econ. Rev. 2007, 18, 287-308. [CrossRef]

14. Wang, D.; Cai, F.; Zhang, G. Employment and Wage Determination of Rural Migrant Workers: The Role of Education and Training. China Econ. Q. 2008, 7, 1131-1148.

15. Sun, W.; Bai, C.; Xie, P. The Effect on Rural Labor Mobility from Registration System Reform in China. Econ. Res. J. 2011, 1, 28-41.

16. Wang, M.; Cai, F. Experiences and Perspectives of Hukou System Reform. Soc. Sci. Guangdong 2008, 6, 19-26.

17. Zhang, J.; Wang, R.; Lu, C. A Quantitative Analysis of Hukou Reform in Chinese Cities: 2000-2016. Growth Chang. 2019, 50, 201-221. [CrossRef]

18. Zhao, J.; Fan, Y. historical review and realistic reflection on the reform of household registration system since reform and opening up. Rev. Econ. Res. 2019, 10, 120-125.

19. Munshi, K. Networks in the modern economy: Mexican migrants in the U.S. labor market. Econ. Q. J. 2003, 118, 549-599. [CrossRef] 
20. Laszlo, S.; Santor, E. Migration, social networks, and credit: Empirical evidence from Peru. Econ. Dev. 2009, 47, 383-409. [CrossRef]

21. Wu, Z. Self-selection and earnings of migrants: Evidence from rural China. Asian Econ. J. 2010, $24,23-44$. [CrossRef]

22. Crozet, M. Do migrants follow market potentials? An estimation of a new economic geography model. Econ. Geogr. J. 2004, 4, 439-458. [CrossRef]

23. Poncet, S. Provincial migration dynamics in China: Borders, costs and economic motivations. Reg. Sci. Urban Econ. 2006, 36, 385-398. [CrossRef]

24. Song, Y. What Should Economists Know about The Current Chinese Hukou System? China Econ. Rev. 2014, 29, 200-212. [CrossRef]

25. Meng, L.; Zhao, M. Permanent and Temporary Rural-Urban Migration in China: Evidence from Field Surveys. China Econ. Rev. 2018, 51, 228-239. [CrossRef]

26. Johnson, L. Bordering Shanghai: China's Hukou System and Processes of Urban Bordering. Geoforum 2017, 80, 93-102. [CrossRef]

27. Li, K. Influence of Household Registration System Reform on Rural Labor Force Transfer. Commer. Times 2010, 26, 15-16.

28. Pi, J.; Zhang, P. Hukou System Reforms and Skilled-unskilled Wage Inequality in China. China Econ. Rev. 2016, 41, 90-103. [CrossRef]

29. People's Republic of China Account Registration Ordinance. Available online: http://www.npc.gov.cn/wxzl/ gongbao/2000-12/10/content_5004332.htm (accessed on 29 November 2019). (In Chinese)

30. People's Republic of China Residents' Identification Cards Ordinance. Available online: http://www.npc.gov. cn/wxzl/gongbao/2000-12/06/content_5004460.htm (accessed on 29 November 2019). (In Chinese)

31. Interim Provisions on Urban Population Management. Available online: http://xuewen.cnki.net/ R2007070130001551.html (accessed on 29 November 2019). (In Chinese).

32. Economic Reform Special Issue, Semimonthly 'The Dynamic of Reform'. Available online: http://www.ndrc. gov.cn/fzgggz/tzgg/zhdt/200908/t20090805_294945.html (accessed on 29 November 2019). (In Chinese)

33. Guangdong Provincial Floating Population Service Management Ordinance. Available online: https: //baike.baidu.com/item (accessed on 29 November 2019). (In Chinese).

34. Opinions of the State Council on Further Promote the Hukou System Reform. Available online: http: //www.gov.cn/zhengce/content/2014-07/30/content_8944.htm (accessed on 29 November 2019). (In Chinese)

35. National Bureau of Statistics of China. (2000-2016). Available online: http://www.stats.gov.cn/english/ Statisticaldata/AnnualData (accessed on 29 November 2019). (In Chinese)

36. Zhao, Y. Leaving the Countryside: Rural to Urban Migration Decisions China. Am. Econ. Rev. 1999, 89, 281-286. [CrossRef]

37. Zhao, Y. The Role of Migrant Networks in Labor Migration: The Case of China. Contemp. Econ. Policy 2003, 21, 500-511. [CrossRef]

38. Hare, D.; Zhao, S. Labor Migration as a Rural Development Strategy: A View from the Migration Origin. In Rural Labor Flows in China, 148-178; West, L.A., Zhao, Y., Eds.; University of California Press: Berkeley, CA, USA, 2000.

39. Todaro, M.P. A Model of Labor Migration and Urban Unemployment in Less Developed Countries. Am. Econ. Rev. 1969, 59, 138-148.

40. Fan, Q.; Sun, P.; Tang, Y. Ageneral Equilibrium Analysis of the Impact of Public Infrastructure Investment on Regional Economy. Word Econ. 2004, 05, 58-62.

41. Wei, X. Regional Differences in the Composition of Infrastructure Investment in China. Shanghai Econ. Rev. 2002, 12, 20-25.

42. Chen, Z.; Wang, Q. Education and Regional Economic Diversity. China Popul. Resour. Environ. 2004, 4, 80-84.

43. Cai, J.; Zheng, M.; Liu, Y. Measurement and International Comparison of China's Real Urbanization Level. China Rev. Polit. Econ. 2019, 10, 95-128.

44. Fang, H.; Chen, W.; Chen, C.; Jia, C.; Li, C.; Hou, W. Levels of Urbanization and Parental Education in Relation to the Mortality Risk of Young Children. Int. J. Environ. Res. Public Health 2015, 12, 7682-7696. [CrossRef]

45. Liu, H. Household registration, basic public goods supply and urbanization-empirical analysis based on city characteristics and migration population monitoring data. Econ. Theory Bus. Manag. 2019, 8, 60-74. 
46. Chen, Y. Village-Based Networks and Wages of Rural to Urban Migrants: Estimating the Causal Effects of Networks Using Combined Identification Strategies. Soc. J. 2012, 4, 68-92.

47. Zhang, Z.; Donald, J.T. Social origins, Hukou conversion, and the wellbeing of urban residents in contemporary China. Soc. Sci. Res. 2013, 42, 71-89. [CrossRef]

(C) 2020 by the authors. Licensee MDPI, Basel, Switzerland. This article is an open access article distributed under the terms and conditions of the Creative Commons Attribution (CC BY) license (http://creativecommons.org/licenses/by/4.0/). 